Cahiers $d u$ MONDE RUSSE

\section{Cahiers du monde russe}

Russie - Empire russe - Union soviétique et États indépendants

$49 / 1 \mid 2008$

Réformes et société en Asie centrale tsariste et soviétique

\title{
Rural Dynamics and Peasant Resistance in Southern Kyrgyzstan, 1929-1930
}

BENJAMIN H. LORING

\section{OpenEdition}

\section{Journals}

Édition électronique

URL : https://journals.openedition.org/monderusse/9124

DOI : $10.4000 /$ monderusse. 9124

ISSN : $1777-5388$

Éditeur

Éditions de l'EHESS

Édition imprimée

Date de publication : 25 février 2008

Pagination : 183-210

ISBN : 978-2-7132-2195-8

ISSN : $1252-6576$

Référence électronique

BENJAMIN H. LORING, «Rural Dynamics and Peasant Resistance in Southern Kyrgyzstan,

1929-1930", Cahiers du monde russe [En ligne], 49/1 | 2008, mis en ligne le 01 janvier 2009, consulté le 03 septembre 2022. URL : http://journals.openedition.org/monderusse/9124 ; DOI : https://doi.org/ 10.4000/monderusse.9124 
chercher : repérer : avancer

Cet article est disponible en ligne à l'adresse :

http://www.cairn.info/article.php?ID REVUE=CMR\&ID NUMPUBLIE=CMR 491\&ID ARTICLE=CMR 4910183

Rural Dynamics and Peasant Resistance in Southern Kyrgyzstan, 1929-1930

par BENJAMIN H. LORING

Editions de I'EHESS | Cahiers du monde russe

2008/1 - Vol 49

ISSN 1252-6576 | ISBN 9782713221958 | pages 183 à 210

Pour citer cet article :

_LORING B., Rural Dynamics and Peasant Resistance in Southern Kyrgyzstan, 1929-1930, Cahiers du monde russe 2008/ 1, Vol 49, p. 183-210.

Distribution électronique Cairn pour les Editions de l'EHESS.

(C) Editions de l'EHESS. Tous droits réservés pour tous pays.

La reproduction ou représentation de cet article, notamment par photocopie, n'est autorisée que dans les limites des conditions générales d'utilisation du site ou, le cas échéant, des conditions générales de la licence souscrite par votre établissement. Toute autre reproduction ou représentation, en tout ou partie, sous quelque forme et de quelque manière que ce soit, est interdite sauf accord préalable et écrit de l'éditeur, en dehors des cas prévus par la législation en vigueur en France. Il est précisé que son stockage dans une base de données est également interdit. 


\section{RURAL DYNAMICS AND PEASANT RESISTANCE IN SOUTHERN KYRGYZSTAN, 1929-1930*}

In the fall of 1928, Soviet and party leaders of the Kyrgyz Autonomous Republic resumed the Civil War practice of requisitioning grain. The requisitioning relied on the "Urals-Siberian method" - forced deliveries and the suppression of private trade - and marked the end to the New Economic Policy (NEP). It was followed later by dekulakization (the dispossession and deportation of purportedly rich, exploiting peasants) and collectivization, both of which provoked intense resistance from the peasantry. In the fall of 1929 and again in the summer of 1930, disorders and popular rebellion spread across vast swaths of rural Kyrgyzstan, ${ }^{1}$ mirroring similar patterns throughout the Soviet Union. ${ }^{2}$

\footnotetext{
* The research for this article was supported in part by grants from IREX (International Researches and Exchanges Board) and ACIE (American Councils for International Education) with funds provided by the United States Department of State through the Title VIII Program and the IREX Scholar Support Fund. None of these organizations is responsible for the views expressed. I would like to thank Lynne Viola and the other participants of the SSRC Eurasia Program Dissertation Development Workshop "Violence in Eurasia" at Yale University in March 2007 for their critiques and suggestions on an early version of this paper. I am also grateful to Gregory L. Freeze (Brandeis University), Daniel Prior (Miami University, Ohio), and Christian Teichmann (Humboldt University) for their comments on subsequent drafts. Finally, I am thankful to the three anonymous reviewers at Cahiers for their comments and suggestions.

1. In this article, the term "Kyrgyzstan" refers to the territory of the present-day Kyrgyz Republic. From 1927 to 1936, this territory was known as the Kyrgyz Autonomous Soviet Socialist Republic (ASSR) and was part of the Russian Soviet Federative Socialist Republic (RSFSR).

2. See, for example, Lynne Viola, Peasant Rebels under Stalin (New York: Oxford, 1996), Adrienne Lynn Edgar, Tribal Nation: the Making of Soviet Turkmenistan (Ithaca, NY: Cornell, 2006), ch. 7 .
} 
When described this way, the dynamics of state action and resistance to it seem clear: the state bears down on society and society resists through demonstrations, revolts, murders, as well as less confrontational forms: flight, sabotage, and other "everyday forms of peasant resistance."3 In fact, as many scholars have pointed out, both state policy and resistance to it were diverse and complex. ${ }^{4}$ Policy reflected lower-level officials' interpretations of state priorities and their capacity for implementing them. It has become a truism that neither the Soviet state nor Soviet society constituted a monolith; divisions and tensions within each locale shaped outcomes at the local, district, regional, republic, and all-Union levels. The nature of the reaction to state policy was likewise problematic: Soviet officials often ascribed political motivations to actions which may or may not have had them. 5 The aims, forms, and timing of actions subsequently deemed acts of resistance varied and bore the imprint of local economic and social dynamics. This article aims to examine such variations within the context of collectivization in 1929 and 1930 in southern Kyrgyzstan.

The article attempts to contribute to the already substantial literature on Central Asia under Soviet rule. To be sure, peasant resistance to Soviet collectivization in 1929-1930 has been a major focus of research, especially in the last fifteen years. ${ }^{6}$ Most studies, however, have looked primarily at Russia proper. ${ }^{7}$ In the case of Central Asia, the scholarly community has only recently begun paying attention to resistance to collectivization, focusing thus far primarily on Kazakhstan and Turkmenistan. ${ }^{8}$ Much of the scholarship, moreover, does not include in its analysis

3. By this, I am referring to the term James C. Scott uses to describe "the ordinary weapons of relatively powerless groups." See his Weapons of the Weak: Everyday Forms of Peasant Resistance (New Haven, Conn.: Yale, 1985), Xv-xxii.

4. Lynne Viola, "Popular Resistance in the 1930s: Soliloquy of a Devil's Advocate" in Michael David-Fox, Peter Holquist, and Marshall Poe, eds., The Resistance Debate in Russian and Soviet History (Bloomington, IN: Slavica Publishers, 2003), 70-80.

5. Ibid., 75 .

6. Two of the most widely cited works are Lynne Viola, Peasant Rebels under Stalin (New York: Oxford, 1996) and Sheila Fitzpatrick, Stalin's Peasants: Resistance and Survival in the Russian Village after Collectivization (New York: Oxford, 1994). Others important contributions include Tracy McDonald, “A Peasant Rebellion in Stalin's Russia: the Pitelinskii uprising, Riazan, 1930," in Lynn Viola, ed., Contending with Stalinism: Soviet Power \& Popular Resistance in the 1930s (Ithaca, NY: Cornell University Press, 2002), 84-108, and James Hughes, Stalinism in a Russian Province: a Study of Collectivization and Dekulakization in Siberia (New York: St. Martin's Press, 1996), especially p. 92-159.

7. One such exception is Bruce Grant, "An Average Azeri Village (1930): Remembering Rebellion in the Caucasus Mountains," Slavic Review ,63, 4 (2004): 705-31.

8. For an example of the newer scholarship on Kazakhstan, see Turganbek Alleniiazov, “'K zachistke bandelementa pristupit' nemedlenno...'. Dokumenty Semipalatinskogo OGPU 1931 g." in Istoricheskii Arkhiv 11/3 (2003): 137-154, Isabelle Ohayon, La sédentarisation des Kazakhs dans l'URSS de Staline: Collectivisation et changement social, 1928-1945 (P.: Maisonneuve et Larose, 2006), 179-221, and Niccolò Pianciola, "Famine in the Steppe: the collectivization of agriculture and the Kazak herdsmen, 1928-1934," Cahiers du Monde russe, 45, 1-2 (2004), 154-170. For Turkmenistan, Adrienne Lynn Edgar's recent monograph provides an excellent study of resistance to collectivization. See Adrienne Lynn Edgar, Tribal Nation: the making of Soviet Turkmenistan (Princeton, NJ: PUP, 2005), chapter 7. 
regional and sub-regional dynamics, the examination of which can provide a context for acts of resistance in Central Asia. ${ }^{9}$ The article incorporates archival materials from central (Moscow), republic (Bishkek), as well as regional (Osh) repositories to situate events locally and provide their immediate context. The study draws primarily on documents of state, party, and OGPU (secret police) organs. Naturally, this source base reflects the biases and limitations of Soviet agents and officials. At the same time, however, the volume and detail of the materials make them valuable to examining the complex interactions between the Soviet government and rural society.

Despite southern Kyrgyzstan's ethnic, cultural, and economic diversity, the region witnessed a series of similar violent demonstrations and revolts across its territory in the spring and summer of 1930 . The grievances of the rural population included not only forced collectivization, but also a string of increasingly onerous policies, which the agents of the Soviet regime had clumsily imposed over the previous several years. Although these policies affected different segments of the population in different ways, by the spring of 1930 they had driven large segments of the agrarian population to open rebellion. Forced collectivization was merely the trigger for an explosion of long-simmering discontent. Lynne Viola has written, "[o]nly the combination of shared interests under threat from a common foe in the context of extreme and generally sudden and short-term duress could serve to paper over the normal everyday divisions that run through a society." 10 In southern Kyrgyzstan, this extreme, sudden, short-term duress was the collectivization campaign of January-March 1930, but it came at the end of a longer period of growing tensions.

The article is divided into five sections. The first three discuss the socioeconomic and political context for the resistance. They demonstrate that, while the Soviet state's policies were universally unpopular, these policies had different consequences for different segments of the population. In the last two sections, the article examines acts of resistance both before and after the November plenum. To avoid mischaracterization, the article will only look at acts of "active" resistance: mass demonstrations, assault of murder of state personnel, destruction of state establishments, and so forth. The article finds that the resistance initially varied in its form, timing, and intensity according to the nature of the economic and social impact of state policies on the local population in different areas of the region. Later, the resistance took on a generalized form as a large contingent of the population in various localities took part in the resistance. The article attempts to explain this shift in the conclusion.

9. To be sure, the above-cited works by Bruce Adams and Tracy McDonald take pains to reconstruct the local context for acts of resistance to collectivization.

10. Viola, "Introduction" in Viola, ed., Contending with Stalinism... 


\section{“Cottonization" and its effects, 1925-1928}

Soviet economic policy in the late 1920s included plans to integrate Central Asia into the all-union Soviet economy; the goal was to make Central Asia a chief source of raw materials (above all, cotton) for Soviet industrialization. ${ }^{11}$ In the $1920 \mathrm{~s}$, Central Asia (without Kazakhstan) accounted for 75 percent of the cotton grown in the Soviet Union. ${ }^{12}$ Although the region had restored pre-war production levels by 1927 , it still could not meet the demands of the Soviet textile industry, which had to import 41 percent of the necessary cotton fiber. ${ }^{13}$ In a speech in September 1927, Isaak Abramovich Zelenskii, the secretary of the party's Central Asia Bureau, exhorted party officials and state bureaucrats to "liberate" the Soviet Union from dependence on capitalism by increasing the production of cotton in Central Asia. ${ }^{14}$ At the same time, however, the productivity of Central Asian cotton farming had fallen since Tsarist times, as it was based on small-holder production, and only by increasing the sown acreage could production levels be maintained. ${ }^{15}$ Therefore, the rising demand for cotton forced the party leadership in Central Asia to seek out new ways of achieving higher levels of cotton production both by expanding and intensifying it.

As the principal economic planning agency for Central Asia, the Central Asian Economic Council (SredAzEKOSO) had used a variety of ways to increase cotton production. Between 1922 and 1926, the state Cotton Committee (Khlopkom) had purchased cotton at a fixed ratio of 2.5-3 times the price of grain. ${ }^{16}$ This, however, turned out to be a very costly policy, as the state's purchases increased. In November 1926, the Central Asian Economic Council replaced this scheme with one of subsidizing wheat sales to cotton farmers: state-run cooperative stores

11. In Central Asia, industrialization itself had always been secondary to agricultural development: compared to the European parts of the Soviet Union, Central Asian industrial expansion was very modest in absolute terms (though significant relative to pre-Revolutionary levels) throughout the 1920s and 1930s, and migrants from European areas of the USSR staffed what few mines and factories did exist. See Alec Nove and J.A. Newth, The Soviet Middle East: A Communist Model for Development (New York: Praeger, 1966), 46-47, William Fierman, “The Soviet 'Transformation' of Central Asia," in William Fierman, ed., Soviet Central Asia: the failed transformation (Boulder, CO: Westview Press, 1991), 18-19, Ian Murray Matley, "Industrialization (1865-1964)," in Edward A. Allworth, ed., Central Asia: 130 years of Russian dominance, a historical overview (Durham, NC: Duke University Press, 1994), 330-331, Alexander G. Park, Bolshevism in Turkestan, 1917-1927 (New York: Columbia, 1957), 311

12. R.W. Davies, The Socialist Offensive: the collectivization of Soviet agriculture, 1929-1930 (Cambridge, MA: Harvard University Press, 1980), 19.

13. Ian Murray Matley, "Agricultural Development," in Edward A. Allworth, ed., Central Asia: 130 years of Russian dominance, a historical overview (Durham, NC: Duke University Press, 1994), 289-290.

14. “Sredneaziatskie respubliki - syr'evaia baza SSSR”, Pravda, 02 October 1927, p. 4.

15. Park, Bolshevism in Turkestan, 1917-1927,313-319.

16. Park, Bolshevism in Turkestan, 314-315; OOGA (Oshskii oblastnoi gosudarstevennyi arhiv - State Archive of Osh Oblast), f. 1, op. 1, d. 88, 1.8 (Prezidium SredAzEKOSO, "Protokol zasedaniia," 18.10.1926). 
charged 1 ruble 50 kopecks per pood ${ }^{17}$ of wheat to cotton growers; 1 ruble 81 kopecks for everyone else in cotton-producing regions (this while locally grown wheat was selling for 2 rubles 20-30 kopecks per pood in markets). ${ }^{18}$ In 1926-1927, therefore, the state successfully expanded cotton production by making local grain production less attractive, but in turn, it had to shoulder the burden of providing cheap grain to cotton-growing regions. The Central Asian Economic Council found that it could not ensure the quality of the state-supplied wheat, which could be of such poor quality that peasants frequently preferred to pay more for the higherpriced locally grown equivalent. ${ }^{19}$ By 1927 , state economic bodies had already run up against the limits of "cottonization" and began seeking alternatives to subsidies to expand cotton production.

The Land and Water Reforms - party-directed programs of property redistribution in each of the Central Asian republics - offered just such an opportunity. In general, the Land and Water Reforms of the mid-1920s were designed to accomplish in Central Asia what the agrarian revolution of 1917-18 had achieved in European Russia, namely the dispossession of landlords and religious institutions and the equalization of property-holdings among peasants..$^{20}$ The reforms' principal goal was therefore not economic development, but social equalization; the reforms did, however, create an important role in the agrarian economy for the state, as its institutions - most importantly, the Cotton Committee - now functioned as the principal creditors in areas affected by the land reforms. ${ }^{21}$ As most peasants relied on credit, the Cotton Committee now used credit schemes to force peasants to increase deliveries of cotton. This remained the principal means of expanding the acreage under cotton cultivation until the forced collectivization of 1930.

Increasing cotton production also had important ramifications outside cottongrowing areas. In the first place, an exclusive focus on cotton production meant that grain and draft animals increasingly had to come from other areas of Central Asia. By 1927, officials were requisitioning draft animals for use in cotton-growing areas affected by the land reform. ${ }^{22}$ Grain imports from Russia reached all-time highs by

17. A pood was a Russian unit for measuring grain roughly equal to 36.11 pounds or 16.38 kilograms.

18. OOGA, f. 1, op. 1, d. 88, 1.8-11 (Prezidium SredAzEKOSO, "Protokol zasedaniia," 18.10.1926).

19. OOGA, f. 1, op. 1, d. 88,1. 28 (Prezidium SredAzEKOSO, "Protokol No. 10,” 02.11.1926).

20. I.A. Zelenskii, "O zemel'no-vodnoi reforme v Srednei Azii (doklad na plenume SredAzBiuro TsK VKP(b) ot 14 marta 1925 g." in I.S. Kraskin, ed., Zemel'no-vodnaia reforma v Srednei Azii: sbornik materialov (M.: Moskovskii Rabochii, 1927), 24-27.

21. One survey cited by a Soviet economist claimed that of 1132 households in Margelan uezd of Ferghana Oblast in Uzbekistan, the Cotton Committee supplied 85 percent of the credit used, a far larger amount than the 10 percent supplied by private individuals. See A. Davydov, “Zemel'naia reforma i kredit", Narodnoe khoziaistvo Srednei Azii 1925, no. 12-13, 21.

22. TsGA PD KR (Tsentral'nyi gosudarstvennyi arhiv politicheskoi dokumentacii Kyrgyzskoi Respubliki - Central State Archive for Political Documentation of the Kyrgyz Republic), f. 10, op. 1, d. 130, 1.65-74 ("Plan zagotovki rabochego skota dlia zemleustraivaemogo naseleniia iuzhnykh kantonov v 1927-1928 godu," 1927). 
1927, exceeding prewar levels by 25 percent, according to official data. ${ }^{23}$ At the same time, however, the Central Asian Economic Council made a policy of only requesting grain from outside Central Asia when it had exhausted supplies in the region. ${ }^{24}$ As grain was less forthcoming from outside after 1927, the Council and other economic organs had increasingly to rely on food supplies within Central Asia to make up the difference.

This burden fell heavily on the grain-growing areas of Kyrgyzstan, especially the northern ones, in spite of the protests of officials in Kyrgyzstan. In the winter of 1927-1928, as in the rest of the Soviet Union, state organs in Kyrgyzstan began to requisition grain. Aziiakhleb, the state grain trust in Central Asia, was to redistribute this grain to cotton-growing regions. Determined to exceed the original quotas on grain deliveries to the People's Commissariat of Trade, the Kyrgyz oblast party committee (or obkom, the chief party organ in the Kyrgyz autonomous republic) sent a delegation of its members into several of the grain-growing districts of northern Kyrgyzstan in April 1928. Their success in coercing grain from reluctant producers only led to higher quotas: Zelenskii even demanded overfulfillment of the grain delivery plan by 100,000 poods (1,600 metric tons, about 66 percent of an already ambitious quota) in order to provide the grain for further "cottonization." 25 In response, V.P. Shchubrikov, then the secretary of the obkom, sent off a telegram declaring Zelenskii's demands "completely impossible" in the face of that year's widespread crop failure throughout the southern districts and dzhut (massive livestock die-offs after heavy icing in pastoral areas) in the north. ${ }^{26}$ Zelenskii held firm, and the obkom bureau acquiesced to his demands: one month after confiscating all the grain that obkom plenipotentiaries (upolnomochennye) could find, they repeated the exercise to the consternation of the grain-producing peasantry in the northern districts. ${ }^{27}$

The grain requisitions campaign in spring 1928 marked an important turning point for the Communist leadership in Kyrgyzstan: it was the last time that the obkom leadership, specifically the European obkom secretary, objected to the demands of Zelenskii's Central Asia Bureau. Within a year, Shchubrikov had been replaced by Mikhail Maksimovich Kul'kov, a former assistant to D.I. Manzhara, the Central Control Commission plenipotentiary in Central Asia (upolnomochennyi TsKK v Srednei Azii) and a staunch ally of Zelenskii. Kul'kov

23. Matley, “Agricultural Development," 287.

24. OOGA, f. 1, op. 1, d. 88, 1.73-84 (Prezidium SredAzEKOSO, "Vypiska iz protokola No. 13,"1926-12-15/16).

25. TsGA PD KR, f. 10, op. 1, d. 155, 1.3 (Ispolbiuro Kirgizskogo Obkoma, "Protokol No. 22," 13.05.1928).

26. TsGA PD KR, f. 10, op. 1, d. 155, 1.16 (V.P. Shchubrikov, 12.05.1928). In fact, dzhut ultimately killed off 12 percent of the republic's livestock in the winter of 1927-28, see M.G. Sakharov, ed., Osedanie kochevykh i polukochevykh khoziaistv Kirgizii (M.: Tsentral'noe biuro kraevedeniia, 1934), 84.

27. TsGA PD KR, f. 10, op. 1, d. 155, 1. 3; TsGA PD KR, f. 10, op. 1, d. 181, 1. 135 (F. Kekin, "No. 7/04273," 22.07.1928). 
exhibited no independence from the Central Asia Bureau during his two-year tenure as party secretary. The obkom, with the occasional exception of its member Iusup Abdrakhmanov, ${ }^{28}$ raised no more objections to the increasingly burdensome requisitions targets from Moscow and Tashkent under his leadership.

\section{Southern Kyrgyzstan, 1925-1929}

In March-April 1929, the obkom and Central Executive Committee (CEC) ${ }^{29}$ of the Kyrgyz ASSR in Frunze cobbled together Osh okrug from Osh and Jalalabad cantons, the two regional subdivisions of southern Kyrgyzstan..$^{30}$ The large territory included wide demographic and climatic variation, encompassing over 400,000 inhabitants in 10 districts (raiony). Within the okrug, forms of agricultural production varied: in some areas, settled agriculture predominated; in others, nomadic or semi-nomadic pastoralism did. In most districts, the two were mixed. Forms of agricultural production, along with the social and ethnic make-up of the inhabitants, were primary considerations for economic planners and party officials in drawing up the districts. The republic's economic planners and political leadership saw the development of Osh okrug in terms of three distinct agricultural zones: cotton, grain, and livestock..$^{31}$

\section{The Cotton Zone}

The cotton zone of Osh okrug was the most densely populated part of the Kyrgyz territory. It was located in the low-lying areas of the Ferghana valley assigned to the Kyrgyz autonomy during the national delimitation of 1924, comprising AravanBuria and the lower reaches of Bazar-Kurgan and Jalalabad districts as well as smaller swaths of Kyzyl-Kiia and Uzgen district. According to official sources, the population in these areas was overwhelmingly agrarian and included many Uzbeks. Sedentary agriculture had predominated in these areas before the Russian conquest

28. Abdrakhmanov, the chairman of the Council of People's Commissars (Sovnarkom) of the Kyrgyz ASSR, wrote a letter to Stalin in November 1929 objecting to the interference in Kyrgyzstan's economic development by economic bodies in Tashkent and Moscow. See Abdrakhmanov to Stalin, Moscow, November 1929 in Iusuf Abdrakhmanov, Izbrannye trudy (Bishkek: Sham, 2001), 183-186.

29. The Central Executive Committee was elected by the Congress of Soviets of the Kyrgyz ASSR to be the leading body of the state apparatus in the autonomous republic.

30. Between 1926 and 1929, the Kyrgyz ASSR was made up of seven cantons (kantony): Osh, Jalalabad, Talas, Frunze, Chui (merged with Frunze canton in 1928), Karakol, and Naryn. See map p. 193.

31. Grain production remained an extremely important activity in southern Kyrgyzstan throughout the interwar period. This was mostly due to the unsuitability of many areas to cotton-growing, due either to their higher elevations or lack of adequate irrigation for cotton cultivation. 
in the mid-nineteenth century, but cotton, not grain, made up a growing portion of the region's agricultural production from 1921 on.

Well before mass collectivization, the inhabitants of Osh okrug had experienced the state as an invasive and disruptive force. In the fall of 1927, the cottonproducing areas of southern Kyrgyzstan underwent the Land and Water Reform, which oversaw widespread land redistribution as well as a state takeover of water allocation. Like the parallel policy implemented previously in Uzbekistan and Turkmenistan, the reform represented an attempt to equalize peasant landholdings, incorporate large parts of the peasantry into trade and production cooperatives, rationalize and control land and water use, and, significantly, dissolve the waqfs (endowments of land) which had supported the remaining religious schools and institutions (the schools, too, were officially disbanded). As in the earlier reforms, this one had not only the political goal of making society in southern Kyrgyzstan more equal, but also the economic goal of rationalizing land use and encouraging the production of technical crops, chiefly cotton. ${ }^{32}$ State and party officials had a further (if tacit) objective: to confiscate private wealth in the countryside and make the state the sole creditor and purchaser of cotton. By dispossessing the richest peasants and creating state-controlled credit cooperatives, Soviet officials could dictate what farmers grew and how much they received for it. In effect, the Soviet regime substituted private exploitation with a state version: instead of paying off debts to a lender or sharecropping for a landlord, the farmers of the Ferghana and elsewhere were now indebted to the state and subject to its demands. The state's priority was cotton, and it enforced its priorities by offering advances of money, seed, water, or equipment in exchange for contractual obligations to deliver specified amounts of cotton. ${ }^{33}$ While the productivity of cotton-growing in southern Kyrgyzstan declined after the reform, the state was able to obtain a larger amount of cotton through these schemes: according to official statistics, deliveries of cotton to state organs increased 38.1 percent between 1925 and 1928.34

The agrarian population of southern Kyrgyzstan, no doubt apprised of the changes in neighboring Uzbekistan, reacted to the land reforms in a variety of ways. Land commissions, which assessed property for confiscation and redistribution, frequently encountered staunch resistance from villages: though this rarely turned violent, many peasants resisted assessments, hid land-holdings and farm implements with poorer neighbors, and sought to mislead local officials. ${ }^{35}$ In the

32. "O zemel'no-vodnoi reforme (tezisy)" (resolution of the Second Plenum of the Obkom VKP(b), 24-27.06.1927) in Kommunisticheskaia partiia Kirgizii, 142-144., TsGA PD KR, f. 10, op. 1, d. 99, 1. 42-44 (“Tezisy k dokladu o zemel'no-vodnoi reforme”).

33. Benjamin H. Loring, "Building Socialism in Kyrgyzstan: Nation-Making, Rural Development, and Social Change, 1921-1932” (Ph.D. diss., Brandeis University, 2008), 216217.

34. Kirgiziia $v$ tsifrakh: statisticheskii sbornik (Frunze: Gosudarstvennoe statisticheskoe izdatel'stvo-Kirgizskoe otdelenie, 1963), 82.

35. TsGA PD KR, f. 10, op. 1, d. 139, 1. 85-86. (OGPU, “Infsvodka No. 10,” October 1927). 
village of Suzak near Jalalabad, a visiting inspector from Tashkent provided this account of the inhabitants' resistance:

[T]hose subject to confiscations are putting up the stiffest resistance. Concealment of land (by splitting it up or by blatantly hiding it) is the norm. [And] this is happening mostly with large amounts of land. The confiscation work (ushchemlenie) has been completed in one kishlak ${ }^{36}$ (Iangy Suzak). Thirty-four households have been assessed for confiscations. One means of resistance is to increase the number of household members and [thereby] to hide sharecroppers. ${ }^{37}$

In many other villages, poor peasants assisted the land commissions in assessing and dispossessing their richer neighbors. ${ }^{38}$ Although the reform succeeded in undermining communal solidarity, it failed to provide an adequate foundation for cooperative agriculture to take the place of previous economic arrangements. Many peasants found themselves even worse off than they had been before the reform: they now had more land, but lacked the means - tools, draft animals, and technical skills - to exploit it effectively. As a result, cotton yields actually fell between 1925 and 1928, even while the state, thanks to its credit schemes, now claimed a larger share of the total production. ${ }^{39}$

The land reform, however, was not the only policy that caused discontentment in the cotton zone. Dissolution of the waqfs, the campaign to unveil women, and the general assault on religion (anti-religious propaganda, mosque closures, etc.) in 1927-1928 offended the sensibilities of many, causing outrage and, at times, demonstrations against party initiatives. ${ }^{40}$ Chronic shortages in the cooperative retail network, on the one hand, and heavy taxations and restrictions on marketbased trade, on the other, also provoked discontent as peasants had steadily poorer access to consumer goods. ${ }^{41}$ As a result, by the winter of 1928 , many segments of the peasantry deeply resented the Soviet State, according to the OGPU. 42

36. "Kishlak" referred to an older, usually Uzbek, village in the documentation of the Kyrgyz party organization.

37. TsGA PD KR, f. 10, op. 2, d. 192,1. 157-158 (Vainer, letter to Zelenskii, 22.12.1927).

38. Loring, "Building Socialism," 213-214.

39. Ibid., 222.

40. One can see this, for example, in the reaction to March 8th unveiling campaigns in predominantly Uzbek districts: TsGA PD KR, f. 10, op. 2, d.292, 1. 15-16 (Gvozdenko, "Doklad," March 1928).

41. See, for example, the complaints by party members about high prices, poor quality, and deficits in cooperative stores in Naukat district: TsGA PD KR, f. 7, op. 1, d. 243, 1. 5-6 ("Svedeniia ot vsekh chlenov partii," 19.02.1929)

42. TsGA PD KR, f. 10, op. 2, d.278, 1.72-77 ("Politicheskaia informatsionnaia svodka No. 5," 13.01.1928). 


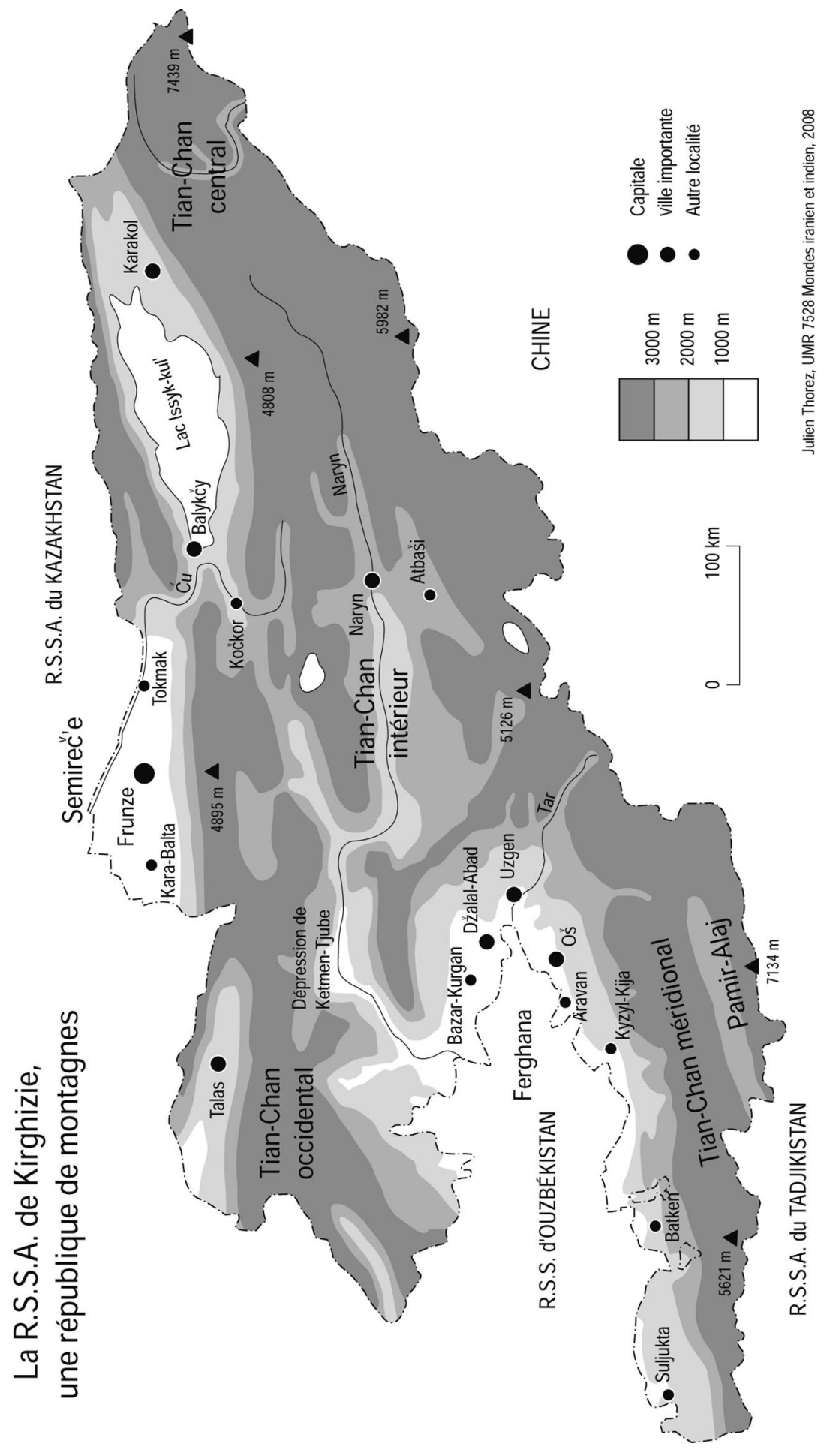


La R.S.S.A. de Kirghizie en 1926 (découpage par canton)

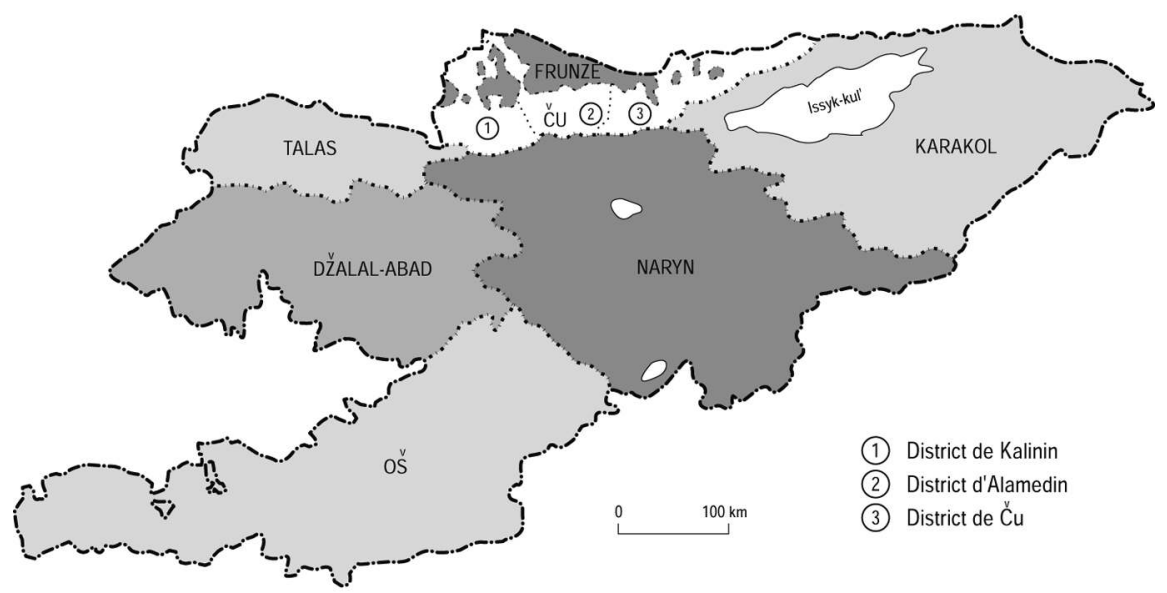

L'okrug d'Oš en 1929-1930 (découpage par district)

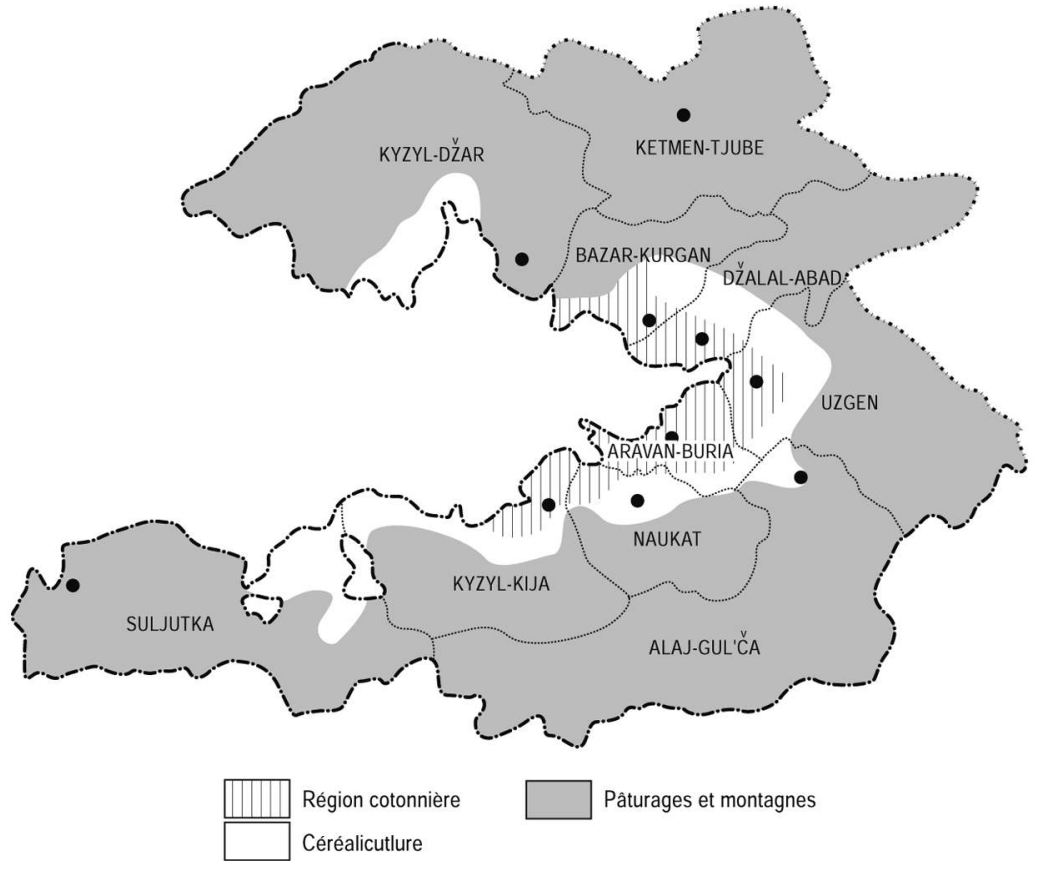




\section{The Grain Zone}

The imports necessary to feed the cotton zone would come in part from Osh okrug's grain zone, especially as shipments from the rest of the Soviet Union declined after 1927 as the Grain Crisis worsened. The grain zone ringed the Ferghana valley at somewhat higher elevations than the cotton zone; grain cultivation made up the bulk of the agricultural activity in the cultivated areas of Uzgen, Kyzyl-Jar, KyzylKiia, and Naukat districts. These areas had a more temperate climate, unsuited to cotton cultivation, and officials of the State Planning Committee (Gosplan) correspondingly deemed them grain-producing districts. ${ }^{43}$ Much of the land of the grain zone had come under tillage since the Russian conquest of the region in the mid-nineteenth century, and the area had been settled more recently and less densely than the cotton zone. These areas were the most ethnically heterogeneous in the okrug, with a mixture of Uzbeks, Kyrgyz, and, in some areas around Jalalabad and Uzgen, Russians and Ukrainians.

As in the cotton zone, the grain zone had experienced increasing state involvement in the economy since the mid-1920s. Also like the cotton zone, some areas in the grain zone underwent a program of land redistribution in 1927-1928; here, however, the reform entailed less redistribution and, consequently, provoked less resistance. Meanwhile, the NEP had revived grain production in these areas of southern Kyrgyzstan, but by the mid-1920s, as in the rest of the Soviet Union, local authorities sought to restrict the activities of private traders (chastniki) and obtain more advantageous terms for state grain purchases. ${ }^{44}$ As discussed above, ensuring adequate grain supplies in order to intensify cotton production became a central concern of the Central Asian Economic Council as early as 1926, and it took an active role in ensuring grain deliveries through economic organizations (Aziiakhleb as well as the cooperative trade network). ${ }^{45}$ As discussed above, the Central Asian Economic Council and economic planning agencies worked to reduce Central Asia's reliance on grain deliveries from Russia. An increase in requisitions from within Central Asia and Kazakhstan offered a temporary solution, as the state increased tax rates on rich peasants and individual smallholders (edinolichniki), thereby privileging cooperative trade networks and collective farms and encouraging their growth. The goal was to ensure that the state incurred no losses and received a maximal share of the output. ${ }^{46}$ Although southern Kyrgyzstan was spared the initial requisitions campaign in April-May 1928

43. I.I. Ibraimov, Bor'ba partorganizatsii Kirgizii za podgotovku uslovii sploshnoi kollektivizatsii sel'skogo khoziaistva (1926-1930 gg.) (Frunze: Kyrgyzstan, 1967), 22.

44. Private trade in grain was unrestricted in southern Kyrgyzstan until August 1927, when, in the face of skyrocketing prices and grain shortages in the state cooperative trade network, the Osh canton executive committee banned private trade. See OOGA, f. 1, op. 1, d. 111, 1. 28 ("Protokol No. 9 zasedaniia frakstii Oshkogo kantispolkoma," 14.08.1927)

45. OOGA, f. 1, op. 1, d. 88, 1.7-11 (Prezidium SredAzEKOSO, "Protokol zasedaniia," 18.10.1926).

46. Ibid. 
(described above) due to crop failure, requisitioning by Aziiakhleb and other state agencies returned to southern Kyrgyzstan in the fall of 1928. The policies of forcing deliveries of grain at low prices ensured advantageous terms for the state but did not endear themselves to the populace: OGPU reports in the fall of 1928 speak of widespread "discontent" (nedovol'stvo) among grain-cultivators with the low purchasing prices offered by Aziiakhleb, the state grain monopoly, and with the quality of trade goods offered through the cooperative trade network. ${ }^{47}$

\section{The Stock-Raising Zone}

Osh okrug's stock-raising zone lay in the mountains and foothills around the Ferghana basin. It comprised Ketmen-Tiube, Kurgart, Batken, Kapchigai, AlaiGul'cha, and Siuliukta districts as well as the mountainous parts of Kyzyl-Kiia, Naukat, Uzgen and Kyzyl-Jar districts. These areas were far less densely populated than the Ferghana basin, and their inhabitants, almost exclusively ethnic Kyrgyz, were generally pastoralists who engaged in field cultivation only as a secondary economic activity. Until the sedentarization campaigns of 1931-1934, most of these pastoralists migrated for several months of the year to high mountain pastures (known as jailoo), leaving their villages mostly empty. The region produced livestock, which was sold at the bazaars of low-lying towns such as Kara-Suu, Osh, Uzgen, Jalalabad and various cities in Uzbekistan through the early 1930s.

State institutions had little presence in these pastoral areas. The Red Army had pursued the last vestiges of the so-called basmachi movement ${ }^{48}$ into the highlands around the Ferghana Valley in 1923, but it was another 2 years before southern Kyrgyzstan was safe enough for the obkom to recall weapons it had issued for selfdefense. ${ }^{49}$ Even though the coercive apparatus of the Soviet government had brought these regions under its nominal control, this was not sufficient to establish a permanent presence in the highlands: these areas had few functioning Soviet institutions such as schools, cooperative trade organizations, village soviets, party and Komsomol cells, mass organizations like the Koshchi union, and so forth. Hence, according to Soviet social scientists and government officials who studied mountainous areas in both northern and southern Kyrgyzstan, tribal elites (referred to in the Soviet literature as manaps in the north, biis in the south) allocated

47. TsGA PD KR, f. 10, op. 1, d. 181, 1.163-64 (Nikitin, "Spetssvodka No.7 po khlebozagotovitel'noi kampanii," 18.09.1928).

48. The basmachi were Muslim Central Asians who had fought the Tsarist then Soviet regimes from 1916 through the early 1930s. The term is a problematic one from a historical standpoint, as it was not the term by which these fighters referred to themselves, but rather a Russian term applied by the Tsarists/Bolsheviks to their adversaries. The term has, however, come into common usage in Western historical literature to denote Central Asian anti-Soviet guerillas in the 1920 s and 1930 s.

49. Aleksandr Igorevich Pylev, Basmachestvo v Srednei Azii: etnopoliticheskii srez (vzgliad iz XXI veka) (Bishkek: Kyrgyzsko-Rossiiskii Slavianskii Universitet, 2006), 101-102; Loring, "Building Socialism," 74. 
pasturelands and adjudicated disputes, a barter economy predominated, and Soviet institutions outside district centers were practically nonexistent. ${ }^{50}$ Most Soviet observers held the view that these areas remained inaccessible to the regime. Soviet policy toward the mountainous stock-raising zone, therefore, aimed first and foremost at overcoming this inaccessibility and establishing an institutional presence, but these measures were very late in coming: only in 1929 did this zone see substantial state-building activities.

\section{The Grain Crisis: Requisitions and Confiscations, 1929}

The grain shortages of 1928 grew more acute in Osh okrug at the beginning of the first Five-Year Plan in 1929. After failing to secure adequate grain supplies in 1928, requisitions the following summer throughout the RSFSR were even higher, as the Commissariat of Trade mandated high delivery quotas from grain-producing regions. ${ }^{51}$ The increased requisitions were to come from the "kulaks" - the Bolshevik term for rich peasants who exploited "poor" and "middle" peasants. As in the rest of the Soviet Union, state agencies assessed higher fees and taxes from so-called kulaks and barred them from participation in municipal government and the party. ${ }^{52}$ In southern districts, however, the "kulaks" had very little grain to confiscate, as much of their property had already been confiscated in the land redistributions of 1927-1928. Moreover, many small-holders depended on government credit and hence contracted to produce cotton. As early as the summer of 1927, the authorities remarked that Osh canton could no longer feed itself and had become "purely a consumer" of grain. ${ }^{53}$ Efforts in the beginning of 1929 to increase grain production through a state-sponsored sowing campaign did not result in higher yields: instead, grain grew scarcer during the winter and spring. ${ }^{54}$

The Kyrgyz obkom responded by imposing draconian measures to combat private grain trading and increasing quotas for grain requisitions from Osh okrug by

50. TsGA PD KR, f. 10, op. 2, d. 118, 1.11 (Toichinov, 03.08.1926); TsGA PD KR, f. 10, op. 1, d. 131, 1.65 (Tiurin, "Narynskie pastbishcha," 1927) ; P. Kushner (Knyshev), Gornaia Kirgiziia (sotsiologicheskaia razvedka) (M.: KUTV, 1929), 106-7.

51. "Rasporiazhenie Narkomtorga SSSR 'po priamomu provodu' o forsirovanii khlebozagotovok [4 maia 1929g.]" and "Postanovlenie VTsIK i SNK RSFSR 'O rasshirenii prav mestnykh sovetov po sodeistviiu vypolneniiu gosudarstvennykh zadanii i planov,' 27 iiunia 1929 g." in V. Danilov et al., eds., Tragediia Sovetskoi Derevni: kollektivizatsiia i raskulachivanie, 1927-1939, 5 vols., vol. 1 (M.: Rosspen, 1999), 612-614, 659-660.

52. Though non-indigenous state and party officials generally used local terms for "kulaks" (bai, boi) and recognized the existence of indigenous property regimes (for example, charikerstvo, a form of share-cropping and/or labor obligations specific to certain areas of Central Asia), their discussion of rural class relations in Kyrgyzstan usually displayed little understanding of local conditions, and more often than not, they merely substituted Central Asian labels such as "bai” for (equally as misrepresentative) Russian ones, such as "kulak."

53. OOGA, f. 1, op. 1, d. 111, 1.28 ("Protokol No. 9 zasedaniia fraktsii Oshskogo kantispolkoma", 14.08.1927).

54. TsGA PD KR, f. 7, op. 1, d. 246,1. 53 (“Svodka No. 7”, 12.04.1929). 
58 percent in July 1929. The state cooperative trade network, meanwhile, continued to degrade, and trade officials had to rely on stop-gap measures - a combination of costly short-term incentives and outright coercion - to ensure grain deliveries. Despite their best efforts, the okrug party organization soon found itself unable to prevent local authorities from openly circumventing the Soviet trade system. In an undated missive from the summer of 1929, the head of the okrug's five-man committee on grain requisitions (khlebnaia piaterka), a former trade official and member of the okrug's party bureau by the name of Chistiakov, issued a missive in which he inveighed against the issuance of grain-trading licenses by local officials:

In the bazaars and villages through all this the private trader (chastnik) is still working; in plain view he pays excessively high prices, buys up grain and carts it off [...] More often than not, arrested wholesale buyers (skupshchiki) have permits from village soviets stating that the bearers are workers who have earned the grain, poor Uzbek peasants who have sown grain on the territory of Kyrgyzstan, or cotton-growers who are buying grain for their own consumption. With such permits, the struggle with unlawful grain-traders has become much more difficult [...] Any functionaries who are exposed to be giving out false, incorrect, or insufficiently inspected permits will be quickly arrested and prosecuted for abetting grain speculation. .55

Village soviet officials, perhaps seeing an opportunity for profit with such high grain prices, perhaps fearing for their fellow villagers' economic and even physical well-being, were openly defying the orders of party officials who sought to channel all available grain into the state trade network. With the grain delivery regime in chaos, little wonder that further deliveries from the grain zone failed to meet the rising demand.

Officials throughout the Soviet Union had been squeezing private traders out of the marketplace and replacing them with the cooperative trade system since the mid-1920s. In southern Kyrgyzstan, however, okrug officials lacked the institutional means to do so as late as 1929 . The five-man grain committee quickly discovered that private traders were buying grain at twice the price offered by the government. The state's trade infrastructure proved utterly incapable of competing with the private trader. Starting in September 1929, Chistiakov ordered that traders be arrested for "profiteering" and brought to Osh for trial. ${ }^{56} \mathrm{~A}$ few days later, on 11 September, he ratcheted up the pressure on state, okrug, and district authorities to ensure grain requisitions, demanding trials "in every village soviet" resulting in "harsh sentences," the arrest of "inactive" (bezdeistvuiushchikh) collective farm chairmen, and prosecutions of anyone in arrears to the state..$^{57}$ These draconian measures were identical to those adopted by grain-delivery officials throughout the Soviet Union: as authorities pressed district and local soviet officials to deliver

55. OOGA, f. 1, op. 1, d. 255,1. 104 (Chistiakov, “Tsirkuliar,” undated).

56. Ibid., 1. 106 (Chistiakov, "Pochto-telegramma," 03.09.1929).

57. Ibid., 1. 108 (Chistiakov, "Prikaz," 11.09.1929). 
grain, prosecutors in each district took coercive measures, including imprisonment and dispossession, against kulaks and private traders. ${ }^{58}$ Lacking the resources either to control the private market or to compete with it, party authorities and prosecutors in the districts of Osh okrug resorted to intimidation and plunder to ensure grain delivery quotas.

While Kyrgyzstan was hardly unique in resorting to coercive means, the weak institutional infrastructure, poor oversight, and the unfamiliarity of most European party officials with local society virtually guaranteed that these onerous policies would be implemented in the most ham-fisted way. According to the instructions from okrug authorities, the grain from kulaks was to be seized by grain requisitioning committees, troikas backed by party members and local authorities. In some districts, however, the plan went awry. In Bazar-Kurgan, for example, the requisitioning committees began in early September confiscating whatever grain they could find, including that of poor peasants, the supposed ally of Soviet power in the countryside. ${ }^{59}$ In Naukat district, the district party committee organized "grain protection brigades" to prevent the transportation of grain outside the district without its authorization. 60 Some village soviet chairmen in Jalalabad were so worried about ensuring grain deliveries through the Kyrgyz republic's cooperative trade network that they refused to allow the Central Asian grain trust, Aziiakhleb, to purchase any grain from their village soviets, even where it was supposed to be available for sale. That frustrated the okrug party committee as well as Aziiakhleb officials in Tashkent, as economic organs there depended on the grain to feed cotton farmers in the rest of Central Asia. ${ }^{61}$ Conflicts over grain deliveries in areas of overlapping jurisdictions were common during collectivization throughout the Soviet Union, but in southern Kyrgyzstan, an area where state and party saturation was low and central control nominal, okrug officials could not avoid bureaucratic infighting over increasingly scarce grain supplies.

Compounding the difficulties of the okrug party bureau was its weak influence over village soviets and other organs of local governance. In part, this weakness stemmed from the bureau's composition: of its five core members, only the secretary, E. Essenemanov, was Kyrgyz. The other four included the aforementioned former trade official Chistiakov, the head of the okrug OGPU Savinskii, an official in the Osh executive committee named Rumiantsev, and the "executive secretary" of the okrug party committee Dvinov. The okrug party

58. Ibid., d. 327, 1.50-56 (Muldagaziev, "Dokladnaia zapiska 'Rabota po Uzgenskomu raionu'," 04.11.1929). Soviet officials in charge of grain requisitions applied these measures widely throughout the RSFSR after the June 1929 amendment to article 61 of the criminal code, see Moshe Lewin, Russian Peasants and Soviet Power: A Study of Collectivization (New York: Norton, 1968), 389-390.

59. OOGA, f. 1, op. 1, d. 256, 1. 20 (Zherdin, "Dokladnaia zapiska," 02.10.1929).

60. TsGA PD KR, f. 7, op. 1, d. 157, 1. 103 (Ispolbiuro Oshokruzhkoma, "Protokol No. 40," 27.09.1929).

61. OOGA, f. 1, op. 1, d. 256, 1. 262 (Chistiakov, "Telegramma," 22.09.1929); Ibid., 1. 263 (Boldyrev, undated telegram). 
bureau maintained close contact with the Central Asia Bureau, the OGPU, and, especially, the obkom in Frunze, all of which were dominated by Europeans from outside Central Asia. The okrug party bureau also maintained contact with the district party committee secretaries, who were generally Europeans or Kyrgyz from northern Kyrgyzstan (as in the case of Turiakul' Aitmatov, ${ }^{62}$ the secretary of Aravan-Buria district party committee). In other words, the overwhelming majority of highly placed Communist party officials in Osh okrug had little knowledge of or personal connection to indigenous society, and the bureau had far closer ties to Russian-dominated organs outside the okrug. Furthermore, communications between the party organizations and lower-tier governing institutions proved highly problematic: not only were many village soviet chairmen unable to read Russian, but they carried on correspondence with higher organs - if at all - in Kyrgyz or Uzbek, virtually assuring that their missives would receive little or no attention. ${ }^{63}$ Although party organizations throughout the Soviet countryside relied on "plenipotentiaries" (upolnomochennye) to accomplish their requisitioning targets, the cadre that directed the campaign was especially alien to the communities of southern Kyrgyzstan.

\section{Deportations and Rebellion, 1929}

While officials at the okrug level struggled to assert their control over the localities in the grain and cotton zones, they regarded the mountainous pastoral districts as a lawless back country. Most officials believed that governance was either entirely absent or corrupt to the point of complete ineffectiveness - a view of the countryside widely held by Soviet officials throughout the Soviet Union. In rural, especially mountainous parts of Kyrgyzstan, however, these beliefs also included suspicion toward clan or tribal affinities. The pervasiveness of "clanno-tribal relations" (rodovo-plemennye otnosheniia), many observers believed, undermined Soviet state-building efforts. In a remote part of the mountainous Kyzyl-Jar district, a later OGPU report characterized Soviet institutions in these terms:

From 1924 to 1929 [...] the Soviet apparat in the region was not only weak. [...] This county (volost) was famous for bribes, extortion, and so forth. Because the

62. Turiakul' Aitmatov (d. 1938) was a Kyrgyz born in the village of Sheker in present-day Talas Oblast. He completed Russian secondary school (real'noe uchilishche) in Aulie-Ata before the revolution and later served in various capacities in the Kyrgyz party organization and Soviet administration in the 1920s and 1930s. In 1937, he was arrested and was executed a year later. He is the father of renowned Kyrgyz author Chingiz Aitmatov (1928-2008). See Zainidin Kurmanov, Natsional'naia intelligentsiia 20-30 godov: vklad v vozrozhdenie gosudarstvennosti kyrgyzskogo naroda i bor'bu s totalitarno-avtoritarnym rezhimom (Bishkek, 2005), 373.

63. This two-tiered bureaucracy, whereby upper-level correspondence was exclusively in Russian and lower-level missives exclusively in indigenous languages, prevailed throughout Kyrgyzstan. Village soviet chairmen, furthermore, often carried on no correspondence with district (raion) executive committees or other organizations during the 1920s. See Loring, "Building Socialism," 151-160, 180-181. 
previous apparat was made up of one clan or another, no matter what the official's class background was, he was under the complete control of the chief (rodonachal'nik) of his clan and carried out taxation and other state functions just as his chief instructed, as though the chief himself had hired the official, promoted him, and was giving the marching orders.

It should be noted that before 1929 in this district no Soviet social reforms have been carried out, and therefore the population only knew Soviet governance because representatives came to collect taxes and other dues. These too were subject to abuses and deficiencies in their practical implementation $[\ldots]^{64}$

In the view of Communist officials, clan or tribal ties undermined Soviet rule in the mountainous pastoral districts. As a result, the officials believed, these regions were lawless and inaccessible to Soviet influence. The following comes from a 1929 report by the Soviet official, Kalpaev, sent to oversee a "summer pastureland (jailoo) soviets" in Alai, an area in the Pamir Mountains south of Osh:

Few [Kyrgyz] are acquainted with Soviet construction. Obedience to local organs and authorities is completely absent. [...] Obedience to tribal elders (aksakaly), to former Islamic judges (kazi), to bais, and to [former Tsarist] county heads (volost'nye upraviteli) continues [...] The population understands nothing of [Soviet] revolutionary law (revoliutsionnaia zakonnost'); purchases and sales of girls, fights, and murders continue $[\ldots]^{65}$

This official likely stressed the weakness of Soviet institutions in order to emphasize the importance and difficulty of his own task, but this passage typifies the prevailing view among European Soviet officials of a lawless, frontier-like back country in the mountainous areas. In their view, the revolution and the reforms it engendered had passed these areas by. Extending the revolution to the mountains, therefore, remained a central goal of the Kyrgyz party organization throughout the late 1920 s.

The first stage of this effort consisted of eliminating the influence of traditional elites. In northern Kyrgyzstan, the Kyrgyz party organization targeted manaps for dispossession and exile from the Kyrgyz ASSR starting in 1926. This campaign entailed first drawing up lists of manaps to be deported and then sending high-ranking officials into the manaps' home districts to coerce the cooperation of local officials and the populace. Finally, the officials from Frunze next deported the manaps out of the Kyrgyz ASSR with the aid of the OGPU. ${ }^{66}$ The OGPU and the CEC in Frunze included southern Kyrgyzstan in their campaigns to dispossess and deport rural elites in February 1929, when their representatives ordered the arrest and deportation of eleven so-called "bai-manaps" and their families from the okrug as well as the confiscation of hundreds of acres of land and thousands of heads of livestock along with yurts and

64. OOGA, f. 1, op. 1, d. 298, 1. 15-16 ("Dokladnaia zapiska o politicheskom sostoianii v b. Chatkal'skoi volosti, v sviazi s vozniknoveniem basmachestva," 16.09.1929).

65. Ibid., d. 194a, 1.24-28 (Kalpaev, "Doklad o deiatel'nosti Alaiskogo Dzhailiaunogo soveta," 1928/1929).

66. Loring, "Building Socialism," 167-180. 
household items. ${ }^{67}$ In several cases, the representatives of the CEC encountered resistance from local officials. In Bel'-Auly, for instance, the chairman of the village soviet along with a crowd of others demanded that the officials from Frunze either free the "bai-manap" Chokobai Sasyev or arrest them as well. ${ }^{68}$ During the arrests of "clanleaders" (rodonachal'niki), the CEC officials recorded local resistance in which, according to their testimony, the entire population of the surrounding environs took part. ${ }^{69}$ One OGPU document contains a detailed description of the resistance of rural Kyrgyz to the campaign in the Chatkal Valley of Kyzyl-Jar District, in what is now Jalalabad Oblast. In February 1929, a seasoned OGPU official, Victor Antonovich Margaitis, ${ }^{70}$ and two militia officers arrested two "bais" in Shakantar and Sumsar village soviets. Local villagers, subsequently deemed in the report "clansmen" of the two arrested men, surrounded and disarmed the two militia officers and threatened Margaitis as he led the captives back to the district center. After a struggle, Margaitis and the officers managed to escape from the crowd with their prisoners. ${ }^{71}$ According to this and other accounts, although these deportation and dispossessions initially targeted only eleven "bai-manaps," they raised the anger of entire communities.

Furthermore, unlike the earlier campaigns against rural elites in the northern areas, the campaign against "bai-manaps" in the south also provoked a revival of the basmachi. According to the OGPU report on Kyzyl-Jar district, the campaign to deport "bai-manaps" and to exclude bais from elections in the village soviets led one local leader, Istambek Chanybekov, to organize an armed "gang" (shaika) and to begin attacks against Soviet interests. Chanybekov did not act in isolation: according to the OGPU, he held a letter from Kurshirmat, ${ }^{72}$ one of the most

67. TsGA PD KR, f. 10, op. 1, d. 225, 1. 141 ("Doklad o vyselenii bae-manapov iz predelov KirASSR v 1929 godu," December 1929).

68. Ibid., 1. 143 .

69. Ibid., 1. 143-144.

70. According to the brief biography contained in his personal fond in the Central State Archive of the Kyrgyz Republic, Victor Antonovich Margaitis was born in 1894 in the town of TemirKhan-Shura (present-day Buinaksk, Dagestan, Russian Federation). His father, an agronomist who hailed from Lithuania, died while he was still a boy. Margaitis completed secondary school (real'noe uchilishche) in 1916, at which time he joined the Imperial Army. In 19201922, he commanded a Red Army cavalry squadron on the Ferghana Front and took part in the storming of Bukhara. From 1922 to 1923, he commanded Cheka/GPU troops in operations against the basmachi around Kokand. Afterward, he remained in Central Asia, serving in various capacities in the OGPU. In 1929, he became a member of the Communist Party. Source: TsGA KR (Tsentral'nyi gosudarstvennyi arhiv Kyrgyzskoi Respubliki - Central State Archive of the Kyrgyz Republic), f. 2722, op. 1, "Predislovie."

71. OOGA,f. 1, op. 1, d. 298, 1. 16.

72. Kurshirmat (Shir Mukhammad-bek Gazi, 1895-1974) was born in the village of Garbaba, near Margelan, Uzbekistan. His father had been an officer in the army of the Kokand khanate and had fought against the Russian invasion before taking up farming. After the uprising of 1916, Shir-Mukhammad-bek joined the guerilla resistance against the Russians and eventually became, in 1920, the leader of the largest basmachi army in the Ferghana Valley. After being defeated by the Red Army in 1923, he fled to Afghanistan, from where he continued to engage in "underground activity" through the 1950s. In 1953, he moved to Pakistan and then on to Adana, Turkey, where he died two decades later. See Pylev, Basmachestvo, 214-217. 
powerful basmachi commanders during the Civil War, which called on all former basmachi to "fight for "Islam." 73 Chanybekov also sought arms and supplies from other basmachi leaders in Talas canton (Kyrgyzstan) and Namangan Oblast (Uzbekistan). In July 1929, his group, acting in concert with other groups, began robbing cooperatives and economic organizations, killing party members, village soviet officials, kolkhoz chairmen, and others working with the regime. ${ }^{74}$ The basmachi similarly revived in other districts as well: by November, the OGPU counted over a hundred active participants in violent, coordinated anti-Soviet resistance throughout Kyzyl-Jar, Ketmen-Tiube, and Bazar-Kurgan districts. To add to this number, Janybek Kazy ${ }^{75}$ and Iarmat Maksum, two basmachi leaders during the Civil War, had begun attacking Soviet establishments and personnel in Kyzyl-Kiia and Uzgen districts along the southern border with Chinese Kashgar. ${ }^{76}$ According to the OGPU's own sources, both insurgent leaders enjoyed significant support from the population: not only did presumed "class enemies" support them, but village soviet chairmen collected funds for Iarmat Maksum, and Janybek's band swelled with scores of fighters. ${ }^{77}$ The given source base - reports by OGPU officers - does not permit independent assessment of popular support, but it is certainly true that the basmachi leaders were more active and more mobile in 1929 than they had been since the Civil War; it is therefore possible to surmise that they enjoyed greater support and assistance from the rural population than previously.

Belatedly, the Osh okrug party bureau realized the strength of the basmachi uprising and sought the aid of the Red Army to protect Soviet assets and personnel. In mid-October 1929, the Osh okrug party bureau declared the entire territory "troubled by basmachiism" (neblagopoluchnyi po basmachestvu).$^{78}$ Dvinov and an

73. OOGA, f. 1, op. 1, d. 298,1. 18.

74. Ibid., 1. 19-22.

75. According to Pylev, Janybek Kazy (Sagynbaev, d. 1939) was "the leader of the Otuzoghly, one of the most influential clans (rody) of the nomadic Kyrgyz in the Ferghana Valley" (Pylev, Basmachestvo, 217). Janybek Kazy led a large contingent of basmachi against Soviet power during the Civil War, but constant conflict with Kurshirmat caused him to make a separate peace with the Bolsheviks in 1922. Janybek Kazy again took up resistance against the Soviet government in 1927 in the wake of the Land and Water Reform and the first campaigns to dispossess and deport manaps in northern Kyrgyzstan. After fleeing into Chinese Turkestan in the summer of 1927, Janybek Kazy made repeated forays into Soviet territory throughout the late 1920s and early 1930s. He likewise participated in the rebellion in Xinjiang against Chinese rule before its suppression by Soviet and Chinese troops. In 1934, he fled to what is now Pakistan and died five years later in Ishkomen (Ghizar district).

76. TsGA PD KR, f. 10, op. 2, d. 360, 1. 107 (Otvetsek Oshokruzhkoma, "Soobshchenie," $05.11 .1929)$

77. TsGA PD KR, f. 10, op. 1, d. 229, 1.132-133 (ob) ("Dokladnaia zapiska o dvizhenii basmacheskikh shaek na territorii Srednei Azii," 01.09.1929); TsGA PD KR, f. 10, op. 2, d. 377, 1. 51-52 (Dvinov, October 1929).

78. TsGA PD KR, f. 10, op. 2, d. 360, 1.96-98 (Ispolbiuro Oshskogo Okruzhkoma, "Vypiska iz Protokola No.43, p. 6," 13.10.1929). Here, the term "basmachiism" connoted both the similar nature of the anti-Soviet resistance to its previous incarnation during the Civil War as well as a surprising continuity in leadership (Janybek Kazy offers an excellent example of this). The use of the term also demonstrates the regime's critical and uncompromising attitude towards the resistance. 
official (upolnomochennyi) of the Central Asian Revolutionary-Military Council (revvoensovet) candidly reported that the poorly devised and implemented policies of the okrug party bureau had led to the current situation. Specifically, the "basmachiism" had stemmed from

political tension in relation to the conduct of grain requisitions, the tax campaign, the bond-selling campaign (zaim), the displacement of grain cultivation [by cotton cultivation], the attack on the wealthy peasantry despite the weak development of the party organization (for a population of 480 thousand, only 1800 members before the purge, and after it a further reduction by $20 \%$ ), the weakness of local Soviet organs, the resilience of clan relations, the lack of a formed village group of supporters (kishlachnyi aktiv) and, without question, the lack of adequate propaganda work during the latest campaigns. ${ }^{79}$

Party and OGPU officials went on to request weapons, munitions, and funds from the Revolutionary-Military Council to arm party members and protect Soviet establishments. ${ }^{80}$

Thus, at the very onset of Stalin's Great Turn in November 1929, the Bolshevik administration in Osh okrug was already in crisis. Outnumbered and poorly coordinated over a sprawling territory, it had exhausted its administrative resources and antagonized large segments of the population just as the November plenum of the Central Committee signaled the introduction of forced collectivization.

\section{Mass-Scale Collectivization and Resistance, January-March 1930}

Despite the precarious situation in which they found themselves in late 1929, Osh okrug party bureau officials as well as party authorities in Frunze outwardly displayed astounding optimism in planning for the republic's collectivization. In the initial aftermath of the November Plenum, republic party leaders intended to introduce mass-scale (sploshnaia) collectivization into only one northern district, Belovodsk. By early February 1930, however, this number had grown to six districts in the republic, including Aravan-Buria and Bazar-Kurgan districts of Osh okrug. ${ }^{81}$ Other districts in the okrug soon followed, and by the end of February, sowing campaign officials (upolnomochennye po posevnoi; generally well-vetted party members from outside the district and often Europeans) were introducing mass-scale collectivization in the entire okrug. ${ }^{82}$ This development was not without resistance from district party officials: often they voiced misgivings and needed to

79. Ibid., 1. 107.

80. Ibid., 1. 108-109

81. RGASPI (Rossiiskii gosudarstvennyi arhiv social'no politicheskoi istorii - Russian State Archive of Socio-Political History) f. 62, op. 2, d. 2258, 1. 39 ("Perechen"”).

82. Ibid, 1. 17. (Bel’skii, "Svodka po voprosu massovykh vystuplenii dekhkanstva v sviazi s kollektivizatsiei v respublikakh,” 20.02.1930). 
be "persuaded," at times with threats to revoke their party cards if they objected. 83 Despite the apprehensions of the district party officials, the newspapers trumpeted the participation of village soviet chairmen and ordinary citizens in the mass-scale collectivization of Osh okrug. ${ }^{84}$ Such "dizziness from success" was common for officials in the first months of the collectivization drive. It seems, however, particularly out of place in a region declared just three months earlier to be "troubled by basmachiism."

Far from expressing the runaway optimism of sowing campaign officials, other observers had a more unsettling view of the collectivization drive in Osh okrug, which was even by Bolshevik standards absurdly optimistic and poorly managed. On 20 February, an official of the party's Central Asia Bureau reported the following from Jalalabad:

The entire okrug is being collectivized. Five districts are officially collectivized, and six others are striving for mass-scale collectivization. The administration and leadership in the localities do not fit the tasks at hand. The plenipotentiaries have been very poorly vetted; almost no one in the district knows what a kolkhoz is or how to organize one. The decision to collectivize fully was carried out by administrative fiat (apparatnym putem) in the district with very small groups of supporters in the villages. At the assembly [of future members of the kolkhoz] the directorate was decided beforehand and put to a vote as a formality. [...] Kolkhozes were explained to the masses thus: signing up for the kolkhoz is obligatory; those who do not sign up will be deprived of water and government supplies, will have heavy tax burdens, and will be deported from [Kyrgyzstan]. Moreover, the cotton quotas have provoked popular discontent. ${ }^{85}$

Seen from the outside, even Soviet agents found the okrug officials' relentless collectivization brash and ham-fisted, a characterization that would have dire consequences for the regional leadership just two weeks later.

The failure to lessen the severity of the new policies led to acts of resistance almost immediately. Even before the large-scale uprisings in March 1930, coercive tactics such as those detailed in the report above had provoked violent acts of resistance by large groups. In the village of Adyr in Uzgen district, a crowd of 150 tore up the kolkhoz sign-up list and, according to an OGPU report, "tried to kill" the plenipotentiary for collectivization. ${ }^{86}$ In a separate incident in the same district, a group of 200 had likewise attacked a plenipotentiary for collectivization. When the "instigators" were arrested, another group broke into OGPU headquarters in an

83. TsGA PD KR, f. 7, op. 1, d. 319, 1. 26-28 ("Informatsionnaia zapiska tov. Dvinovu," 28.02.1930).

84. See, for example, "Bazar-Kurgan budet kollektivnym!" Sovetskaia Kirgiziia, 3 March 1930 , p. 2.

85. RGASPI, f. 62, op. 2, d. 2258,1. 17.

86. Ibid., d. 2141, 1. 78 (PP OGPU v CA, "Massovye vystupleniia dekhanstva za vremia s fevralia po 12e marta"). 
attempt to free the captives ${ }^{87}$ Forced collectivization, the latest in a string of hardships imposed by the regime, was already driving large groups of peasants into open rebellion.

The campaign to "liquidate the kulaks as a class," the accompaniment to massscale collectivization in 1930 throughout the Soviet Union, also provoked widespread anger in southern Kyrgyzstan and further antagonized the very peasants the regime was trying to win over. At first, party activists were instructed to determine who was a bai or "kulak" by conducting inventories of peasant land, livestock, and other possessions. In February 1930, in the wake of the Politbiuro decree of 30 January, Central Asia Bureau organization changed the policy to a simple formula: 2 to 3 percent of the households in areas of mass-scale collectivization in Central Asia were to be "dekulakized" - dispossessed of property and, in some cases, exiled from the district or even sent off to areas of special settlement outside of the republic. ${ }^{88}$ In Osh okrug, as well as throughout the rest of the Soviet Union, richer peasants began to slaughter or sell off their livestock: according to a report by Manzhara, in one village, "kulaks and richer inhabitants of the okrug authorities sold off 40 bulls and have been killing young animals. This outrage has been committed in plain view of village activists, who have taken no action." 89 The okrug party organization was powerless to ensure cooperation at the local level.

In the beginning of March, the violence increased as okrug party officials pursued mass-scale collectivization. On 2 March, disturbances broke out in two separate districts of Osh okrug. In Jalalabad district, after an official from the sowing committee had announced that those not entering the kolkhoz would lose all their property, a crowd of 400 began to beat up government employees. They sacked the local village soviet, smashing furniture and destroying documentation..$^{90}$ Meanwhile, in Aravan-Buria district, a crowd of 250, shouting, "Tear up the kolkhoz lists!" attacked members of the Tepek-Kurgan village soviet during discussions over the charter of a new kolkhoz. ${ }^{91}$ Two days later, disturbances erupted again in Jalalabad district. At first, a large crowd of protesters surrounded the district executive committee building, demanding the release of prisoners (those who had

87. Ibid., d. 2140,1. 97-98 (“Opersvodka No. 2,” February 1930).

88. TsGA PD KR, f. 10, op. 1, d. 220,1. 137 (Kul'kov, "Pochto-telegramma," 27.02.1930). The Politburo decree of 30 January 1930 established three categories of kulaks. The first were deemed "counterrevolutionary kulak activists"; they were to be executed or imprisoned in camps. The second group included the richest kulaks; they were to be dispossessed and exiled out of Central Asia. The third group, making up the bulk of the so-called kulaks, was to be dispossessed and settled outside of the districts of collectivization. See "Postanovlenie Politbiuro TsK VKP(b) 'O meropriiatiiakh po likvidatsii kulatskikh khoziaistv v raionakh sploshnoi kollektivizatsii', 30 ianvaria 1930 g." in V. Danilov et al., eds., Tragediia Sovetskoi Derevni: kollektivizatsiia i raskulachivanie, 1927-1939, 5 vols., vol. 1 (M.: Rosspen, 1999), 126-127.

89. TsGA PD KR, f. 10, op. 2, d. 435,1. 17-18 (Manzhara, “Svodka,” 25.02.1930).

90. RGASPI, f. 62, op. 2, d. 2141,1. 77 (PP OGPU v CA, "Massovye vystupleniia...”).

91. Ibid., 1. 78. 
resisted the collectivization drive), the arrest and execution of 16 collectivization activists, and the restoration of rights of the "disenfranchised" (lishentsy). ${ }^{22}$ They went on to destroy the district women's club and turn in a petition with (in the words of the local OGPU) "a number of counter-revolutionary demands." 93

On 6 March, another crowd of one thousand from the village of Suzak came to the Jalalabad executive committee with demands to tear up the kolkhoz lists, return confiscated grain, arrest the chairman of the kolkhoz and 24 activists, and free those arrested by the OGPU. Preventing the district party secretary from speaking, the crowd killed a party activist and surrounded the headquarters of the OGPU, demanding the release of those arrested. ${ }^{94}$ The next day, rioters destroyed another village soviet office in Jalalabad district, killing a sowing committee official. The revolt, meanwhile, had spread to Bazar-Kurgan district. The following is taken from an OGPU telegram:

On the 7 March in Bazar-Kurgan district a crowd of about 400 demonstrated against collectivization, demanding that authorities dissolve the kolkhozes, not collectivize livestock and farm implements, and not unveil women. At the beginning of the demonstration, the crowd killed two activists (one of them a member of the raikom), wounded a militia officer, broke into the building of the district executive committee, dragging out and then beating up the chairman of the cotton association. The employees of [state] establishments and enterprises have fled their workplaces - the establishments are in danger of being looted.$^{95}$

Another report revealed that the crowd had killed two activists and wounded two others. ${ }^{96}$ The authorities found themselves in danger of completely losing control over the district.

By the next day, 8 March, the revolts in Bazar-Kurgan and Jalalabad each involved over 2,000 participants, many on horseback. These uprisings continued the attacks and looting of the previous few days throughout most of the two districts. The crowds demanded the dissolution of kolkhozes and other Soviet institutions, return of confiscated grain and property, establishment of sharia law, the release of prisoners, and arrest of party officials and activists. ${ }^{97}$ One OGPU report characterized the use of women in the disturbances during the 8 March holiday: "In general, the beating and eviction of officials was conducted by women who were deftly used during the holiday by mullahs and ishans ${ }^{98}$. An oath was

92. The lishentsy were those members of the former elite status groups who were formally disenfranchised by the first constitution in 1918; the class of legal outcasts persisted until 1936.

93. RGASPI, f. 62 , op. 2, d. 2141,1. 77.

94. Ibid.

95. Ibid., 1. 29 (PP OGPU, “Zapiska po provodu,” 08.03.1930).

96. Ibid., 1. 76.

97. Ibid., 1. 76-78.

98. "Ishans" were the blanket Soviet term for rural Muslim clerics who were often adherents to Sufi traditions. 
sworn against the kolkhozes at the mosque. Then, the movement swept over almost the entire district." 99 The prominent role of women in the uprising probably reflected the same calculation among the Uzbek peasantry as it did among peasants in European Russia - namely, that women's demonstrations or riots would more likely go unpunished, and regime forces would use restraint when dealing with them. ${ }^{100}$ On 10 March, a crowd of around 2000 people demanded to see the OGPU plenipotentiary with a petition declaring that the murder of Soviet officials in Bazar-Kurgan had been committed by the entire population. After being rebuffed, they attacked the official. ${ }^{101}$ Thus, throughout several districts, large groups of peasants acted in solidarity against their common foe - the Soviet regime.

Because of the scale and intensity of these uprisings, authorities in Osh okrug were quick to respond. On the second day of disturbances in Jalalabad, a regiment of Red Army soldiers was dispatched to the city along with police and government officials from Osh. ${ }^{102}$ An OGPU report described the government's response to the uprising in Bazar-Kurgan:

The plenipotentiary of the GPU has been given orders to prepare to arrest the instigators and active participants (aktiv), to take a hard line, to show the population the counter-revolutionary nature of the demonstration, [and] in case of need, to use force of arms (primenit' oruzhie). ${ }^{103}$

However, with the end of violent demonstrations, the party apparatus seemed to adopt the opposite course of action: in the aftermath of "Dizzy with Success" and subsequent Politburo directives, the obkom and okrug party committee reversed the decision to collectivize the entire okrug and implemented a series of measures designed to mollify the peasantry. In particular, the okrug party committee sent in a sizeable contingent of party members and 25-thousanders to conduct a propaganda campaign and to right "excesses" (peregiby - namely, forced collectivization, unlawful seizures, improper arrests, and so forth) committed by the collectivization plenipotentiaries; it also sacked several district party secretaries, re-opened livestock markets, temporarily suspended taxation, and agreed to advance money to cotton-, silk- and grain-producers for future deliveries. ${ }^{104}$ Conciliatory policies such as these were common throughout the Soviet Union. In the okrug as elsewhere, they were accompanied by a massive outflow of peasants from collective farms: between 1 April and 15 May 1930, official collective farm enrollments fell from 41,651 to 11,017 peasant households (or from about 42

99. RGASPI, f. 62, op. 2, d. 2141,1. 78 (PP OGPU v CA, “Massovye vystupleniia...”).

100. Lynne Viola, "Bab'i Bunty and Peasant Women's Protest during Collectivization," Russian Review, 45, 1(1986): 38-39.

101. RGASPI, f. 62, op. 2, d. 2141,1. 60-61 (Karutskii, "Vneocherednaia svodka,” 08.03.1930).

102. Ibid., 1. 32 (PP OGPU, “Zapiska po provodu,” 08.03.1930).

103. Ibid., 1. 29 (PP OGPU, “Zapiska...”).

104. OOGA, f. 1, op. 1, d. 346, 1.7 (Politshtab Bazar-Kurganskogo raiona, "Protokol No. 16," 10.03.1930). 
percent to 11 percent of the households in Osh okrug). ${ }^{105}$ The drop in enrollments in the collective farms was greater in the okrug than in other areas of both the Kyrgyz ASSR and the Soviet Union as a whole. ${ }^{106}$ Although party officials at all levels were prepared to quell uprisings by brutal means, they also recognized the necessity of mollifying large segments of the population engaged in key sectors of the economy in an area where the regime lacked both political allies and effective administration at the local level.

The outcome of the February-March collectivization drive in Osh okrug, therefore, took on the same characteristics of those in the rest of the Soviet Union. Soviet officials in the districts dissolved many of the kolkhozes and agreed to turn over lists of those who had joined them. Several of the sowing committee officials, whose behavior had provoked the public's wrath, were removed from their posts or were arrested by the end of March.107 The revolt had coincided with Stalin's "Dizziness from Success" article in Pravda. In its wake, the republic party organization launched inquiries into "excesses": many of the district officials lost their posts and others were forced to make apologies at party meetings and other official venues. This small-scale Thermidor culminated in the censure and reassignment of most of the okrug's party leadership, including Chistiakov, Dvinov, and Essenemanov, in mid-April. ${ }^{108}$ Concerned with reasserting control in the midst of widespread disorder and rebellion throughout southern Kyrgyzstan (especially in mountainous areas), the okrug bureau devoted little energy to the collectivization movement, and enrollments continued to fall through the end of 1930.

The abandonment of the collectivization campaign and bureaucratic reshuffling failed to curb the resurgent basmachi rebellion. If anything, the suppression of the peasant revolts had only strengthened the basmachi, as it sent hundreds of participants fleeing into the mountains, where many joined guerrilla groups. ${ }^{109}$ Although the mountainous districts saw a lull in violence during the winter months of 1929-1930, in May 1930, the basmachi again made forays into Soviet territory from Kashgar, killing state and party officials, sacking government offices, and destroying collective farms in Gul'cha, Uzgen, Naukat, and Bazar-Kurgan districts. In August, to the surprise of a Russian district party official in Uzgen, Slavic peasants from the village of Pokrovskoe united with the basmachi in looting schools, state-run stores, cooperative organizations, and the post office in Kurshab. ${ }^{10}$ The basmachi rebellion all but annihilated the collective farm

105. Loring, "Building Socialism", 324. These reflect only official statistics; due to inflated recruitment figures, lags in reporting exits from the collective farm system, and general administrative disarray, real enrollments were likely lower.

106. Loring, "Building Socialism," 324-325.

107. RGASPI, f. 62, op. 2, d. 2141,1. 76-79, (OGPU, “Massovye vystupleniia...”).

108. TsGA PD KR, f. 7, op. 1, d. 299, 11. 2-3. (Oshokruzhkom, "Protokol zasedaniia 4ogo vneocherednogo plenuma," 15/16.04.1930).

109. TsGA PD KR, f. 7, op. 1, d. 152,1. 19 (Fedotov, "Informatsionnoe pis'mo," 28.07.1930).

110. TsGA PD KR f. 7, op. 1, d. 358, 1. 22-23 (Sergeiuk, 03.08.1930). 
movement throughout much of the okrug and restricted the influence of the okrug party bureau to the lowlands of the okrug and the district centers. The state was only able to suppress the uprising and ensure a nominal degree of control after August 1930, when OGPU forces and volunteer detachments disarmed or scattered the largest basmachi formations. ${ }^{111}$

\section{Conclusion}

In many respects, the mass resistance in Osh okrug in 1929-1930 represented an anti-colonial revolt not unlike the revolt of 1916.112 In the lead-up to both events, southern Kyrgyzstan was a colony and its population suffered from colonialist policies. Predominantly Russian officials before and after the Revolution viewed the region as a producer of raw materials, namely cotton and whatever foodstuffs and draft animals were needed to maximize its production. Considerations of the welfare of the population, while not entirely absent from discussions of Russian and Soviet administrators, were secondary to the needs of the metropole. Moreover, the administrators themselves were not drawn from the local population. Rather, the local administration constituted a proxy for higher organs: at first, the GeneralGovernor's administration and, later, the Russian-dominated obkom. The Tsarist regime before 1916 was not nearly as interventionist as the Soviet regime, but there are important parallels between the Tsarist conscription drive and the mass-scale collectivization of 1929-1930. Like the Tsarists in 1916, the Soviet regime's administrators neither tailored policies from Moscow to the region's specifics nor did they afford local officials significant influence over the implementation. Instead, the Soviet administration relied on "plenipotentiaries" (upolnomochennye) to force the execution of ambitious campaigns. Six years after securing the region during the Civil War, Bolshevik officials still governed the region much as the Tsarist administration had fourteen years before.

At the same time, however, the resistance also had specifically Soviet traits and was quite different from the uprising of 1916. In the first place, acts of resistance signified popular discontent at Soviet policies of the late 1920s, primarily the forced enrollments in the collective farms in grain- and cotton-producing areas. The popular slogans reported by the OGPU, however, also point to other grievances, among them the unveiling campaign, the closure of mosques and sharia courts, and the disenfranchisement of pre-revolutionary elites - all explicitly Soviet initiatives. The resistance also explicitly targeted government institutions and personnel - many of whom were indigenous Central Asians - rather than the Slavic population as a whole. Instead, the Slavic population joined in the destruction of Soviet establishments, uniting with the indigenous rebels against a

111. Loring, "Building Socialism", 326-328.

112. For an explication of the anti-colonial nature of the revolt of 1916, see Daniel Brower, Turkestan and the Fate of the Russian Empire (London: RoutledgeCurzon, 2003), 1-25. 
common enemy. Finally, accounts of the outbreak of violence in Osh okrug read very similarly to those of rebellions throughout the USSR in 1930-1931. This in no small part is due to the conventions of OGPU document production (deloproizvodstvo). It also suggests, however, that the rift between the party leadership and local society in Osh okrug was not significantly greater than it was in other areas of the Soviet Union: if the Bolsheviks were colonialists in southern Kyrgyzstan, so too were they in rural Riazan' or Siberia.

In southern Kyrgyzstan, the resistance evolved from disparate acts to collective action, representing the explosion of tensions that had been building among various segments of rural society over the preceding several years. A wide range of party policies had antagonized the diverse population of Osh okrug. In the grain- and cotton-producing areas, any easing of tensions between the Soviet regime and the rural society under NEP was reversed in $1927-28$ by the Land and Water Reform, restrictions on trade, grain requisitions, unveiling campaign, and the closure of religious institutions. These measures prompted passive resistance (such as sabotage, concealment of property, and foot-dragging), but generally did not provoke violent acts. In the highlands, the campaign against "bai-manaps" in early 1929 led to the revival of the basmachi rebellion and a reprisal of the Civil War with continuity of methods and even personnel. With the onset of collectivization, the disparate groups of the okrug joined in a collective and widespread revolt which took the regime several months to quell.

Center for Eurasian, Russian and East European Studies Georgetown University

bh122@georgetown.edu 